\title{
Navigating the Meanings of Social Justice, Teaching for Social Justice, and Multicultural Education
}

\author{
Hyunhee Cho \\ Ewha Womans University \\ Republic of Korea
}

ABSTRACT: This article uses well-received contemporary scholarshipworks by Iris Young, Nancy Fraser, Morva McDonald, Connie North, and Geneva Gay - to illuminate a high degree of coherence among the substantive meanings of social justice, teaching for social justice, and multicultural education. Based on these relationships, the article suggests that social justice is an inherent feature and goal of multicultural education, and the discourses between teaching for social justice and multicultural education should be mutually associated with one another to more effectively promote social justice. The article closes by outlining personal literacy that has the potential to enrich research and practice in multicultural education.

KEYWORDS: multicultural education, teacher education, social justice, equity education, social justice literacies

The Contemporary Meanings of Social Justice Contextualizing Two Paradigms of Social Justice in Education Negotiating Two Discourses

Social Justice for Flourishing Lives

Concluding Remarks

Notes

Acknowledgment

References

Author Contact

Throughout the world, issues of social justice and equity are becoming a significant part of everyday discourse in education. Teaching for social justice is defined differently in various social contexts because changes in society affect the ways that needs are prioritized (Grant \& Agosto, 2008). In the United States, teaching for social justice has been given numerous labels, such as social justice pedagogy, social reconstructionist teacher education, anti-oppressive education, and social justice teacher education (e.g., Cochran-Smith, 2009; Giroux, 1992; Kumashiro, 2002; McDonald \& Zeichner, 2009). Yet despite these various associations with teaching for social justice, an agreement exists among educators about its purpose or goal, which is to eliminate educational inequalities among 
poor, middle, and wealthy economic classes; majority and minority ethnic groups; and the privileged and powerless, as well as to eradicate punitive forms of school accountability (Zeichner, 2011).

With its focus on preparing teachers to promote educational opportunities for all students, teaching for social justice shares territory with multicultural (teacher) education. However, teaching for social justice is regarded as neither synonymous with multicultural education nor the most common pedagogical approach to multicultural education (Dolby, 2012). McDonald and Zeichner (2009) have explained that social justice teacher education shares certain goals with multicultural education but is conceptually distinct, in that social justice teacher education pays more attention to societal structures that perpetuate social injustices than issues of cultural diversity. They defined social justice teacher education as an extension of the social approaches within multicultural education, explaining further:

Some strands of multicultural education do emphasize notions of justice and social activism and we suggest that social justice teacher education build on and expand these notions, particularly as they are enacted in practice. (p. 597)

However, it is debatable whether the focus on societal structures and social activism is the only space in which social justice teacher education and multicultural education discourses overlap. Social justice is an inherent feature and goal of multicultural education - which has fought on the front line against social injustice for more than three decades in the United States - and therefore it cannot be simply concluded that social justice teacher education is equated with a more critical/transformative version of multicultural education.

This article begins with the premise that understanding the contemporary concept of social justice, in which economic distribution and cultural recognition are considered co-fundamental, is foundational to discussing teaching for social justice. Despite growing efforts to conceptualize teaching for social justice in its relation to the concept of social justice (e.g., Cochran-Smith, 2009), existing scholarship in the field still tends to lean on the deductively constructed meanings of teaching for social justice (i.e., social activism for resisting against the marketization of education enterprise) and finds its theoretical foundations in social justice education, culturally responsive teaching, critical pedagogy, and democratic education (Dover, 2009; Dover, Henning, \& Agarwal-Rangnath, 2016). Even though it is important to attend to the working definitions of teaching for social justice, the philosophical and political roots of contemporary social justice discourses need to be connected more closely to the theory, framework, and practice of teaching for social justice to discuss its nature and process on a deeper level.

This article uses well-received contemporary scholarship-works by Iris Young (1990, 1997, 2011), Nancy Fraser (1995, 1997a, 1997b), Morva McDonald (2005, 2007, 2008), Connie North (2006, 2007, 2009a, 2009b), and Geneva Gay (2012a, 2012b) - to accomplish two goals: (a) to illuminate a high degree of 
coherence among the substantive meanings of social justice, teaching for social justice, and multicultural education; and (b) to suggest that the discourses between teaching for social justice and multicultural education be mutually associated with one another so that they can more effectively serve as a vehicle for promoting social justice. These five female scholars were deliberately selected for their contributions to the transformation of male-dominated social justice discourse. Based on the discussion, a new conceptual tool is suggested, outling what students should know and be able to do to become agents for promoting social justice and equity ${ }^{1}$.

What are the salient features of contemporary discussions of social justice and how are they contextualized in the field of education? How are the goals of multicultural education conceptually connected to those of teaching for social justice? What kind of education do students need in order to become agents for social justice? These questions guide the subsequent sections.

\section{The Contemporary Meanings of Social Justice: Redistribution and Recognition}

The concept of justice has been discussed throughout different times and locations as the primary subject of political philosophy. The multidimensional nature of social justice was discussed by Vincent (2003), Hytten (2006), Gewirtz (2006), and North (2006). Hytten (2006) explained that "one of the primary challenges of social justice work is that its richness and variety cannot be easily reduced, and its advocates are often not speaking to each other or drawing from the same traditions" (p. 225). In spite of its multidimensionality, however, contemporary theories of justice are based on two major concepts: a distribution/redistribution model of justice and a relation/recognition model of justice (Gewirtz, 1998; North, 2006).

The distributive paradigm of justice involves "the principle by which goods are distributed in society" (Gewirtz, 1998, p. 470). This conventional conception of justice reflects John Rawls' (1972) suggestion for a proper balance between competing claims. According to Mapel (1989), Rawls' identification of justice as fairness has been pervasive in contemporary political philosophy of justice in the United States and many other Western countries.

Although the distribution of material and non-material goods is certainly an imperative issue in discussing social justice, many issues related to injustice cannot be addressed within the distributive paradigm (Young, 1990). In fact, many justice-related issues, such as cultural marginalization, stereotyping, and imperialism reflected in the media industry, are not primarily about the distribution of material or non-material goods. Young (1990), in Justice and Politics of Difference, argued that distributive justice is only one part of social justice, and understanding oppression and domination between individuals and groups should be the starting point in discussing social justice. She also contended that existing 
theories and practices of justice tend to collapse all issues of justice into those of distribution, which often leads to misidentification of the remedies for relational injustice as the redistribution of goods and materials.

The relational paradigm of justice is primarily concerned with "the nature of relationships which structure society" (Gewirtz, 1998, p. 470). It questions formal/informal conditions that frame the allocation of wealth, income, and resources (Young, 1990). According to Young (1990), relational justice is more valued in contemporary societies in which collective identities, interdependencies, mutual respect, and equal participations are to be advocated among racially, ethnically, socially, and culturally different individuals and groups.

However, it is debatable whether relational justice should always be prioritized over distributive justice. In regards to the relationships between redistribution and recognition, Fraser (1995) claimed that recent political theory and practices tend to privilege the recognition of social groups at the expense of the redistribution of goods and the division of labor. She suggested that both paradigms are powerful, and a perspectival dualism approach is needed in which redistribution and recognition are considered as co-fundamental and mutually irreducible dimensions of justice.

In order to illuminate the mutuality of these two paradigms in political theory and practices, Fraser (1997b) created a conceptual schema abstracted from the complexities of the real world. Within this framework, she specified redistribution and recognition as economic redistribution and cultural recognition, respectively, and then presented four kinds of political orientations that advocate different remedies for social justice: (a) the liberal welfare state (the politics of affirmative redistribution); (b) socialism (the politics of transformative redistribution); (c) mainstream multiculturalism (the politics of affirmative recognition); and (d) deconstruction (the politics of transformative recognition). Fraser called into question the politics of affirmative recognition, which Young (1990) had emphasized in Justice and Politics of Difference, by arguing that such a politics fails to actualize transformative redistribution. This is because its focus on group differentiation is incompatible with the politics of transformative redistribution, in which group differentiation is subsumed in deeply reconstructed relations of production. She suggested that the politics of transformative recognition, in which all forms of group differentiation (culture and identity) are deconstructed, is needed to effectively integrate the paradigms of recognition and redistribution.

Young (1997) also criticized Fraser's (1997b) dichotomized view of redistribution and recognition, suggesting that it interfered with the understanding that these two struggles are continuous in the real world. More specifically, Young (1997) highlighted that cultural recognition is not an end itself, but rather a means to sociopolitical and economic justice and equity. The examples she used to support this point, equity based on diversity, are worth citing at length:

Many who promote the cultivation of African-American identity, for example, do so on the grounds that self-organization and solidarity in predominantly African-American neighborhoods will improve the material lives of those 
who live there by providing services and jobs (p. 148). Most African American who support culturally based African-American schools and universities, for example, believe that the schools will best enable AfricanAmerican young people to develop the skills and self-confidence to confront white society and collectively help transform it to be more hospitable to African-American success. (p. 158)

Young (1997) referenced Pierre Bourdieu to exemplify that those who acquire or maintain privileged positions in a given society depend partly on "cultural factors of education, taste, and social connection," but access to such enculturation processes depends significantly on "having economic resources and the relative leisure that accompanies economic comfort" (p.154).

In a rejoinder to Young, Fraser (1997a) denied that she prioritized economic redistribution over cultural recognition. She also claimed that she actually framed the two struggles not as a dichotomy but as a perspectival duality in which redistribution and recognition should be articulated in relation to one another. However, Fraser's (1997b) remedy-calling for a deconstructive approach to culture and group identity-still remains a source for injustice because it often discourages members of underrepresented groups from promoting solidarity against denigrating stereotypes and systemized political and economic injustices. In addition, as Honneth (Fraser \& Honneth, 2003) pointed out, her conception of socially just public life tends to remain formal and thereby fails to specify an ethical claim to envision micro-level justices embedded in individuals' face-to-face interactions.

\section{Contextualizing Two Paradigms of Social Justice in Education}

Although Young, Fraser, and Honneth have different views on the remedy for social justice, they share the view that the two paradigms of justice are irreducible and co-fundamental in promoting social justice and equity. It seems, however, quite difficult to apply this perspective of social justice directly to the context of teaching and learning. There are two fundamental questions: What is the role of education in promoting social justice? How can education contribute to both redistribution and recognition? In exploring the role of education in actualizing social justice, I enlisted the scholarship of McDonalds (2005, 2007, 2008), North $(2007,2009 a, 2009 b)$, and other scholars who presented theoretical frameworks for teaching for social justice.

McDonald $(2005,2007,2008)$ proposed four dimensions of social justice that help to understand how it is conceptualized in the field of education. In a qualitative case study of two teacher preparation programs committed to promoting social justice, she presented four different perceptions of teaching for social justice that emerged from prospective teachers (McDonald, 2008), teacher educators (McDonald, 2007), and teacher education programs (McDonald, 2005, 2008). These included teaching for social justice as (a) meeting individual students' needs and providing them with differential supports when necessary; (b) recognizing 
students' opportunity to learn that are responsive to their identification with specific groups such as English language learners and students with special needs; (c) recognizing students' opportunities to learn that are responsive to their affiliation with specific groups based on race, ethnicity, and socioeconomic status; and (d) resisting the institutional level inequities presented in society.

In McDonald's substantive theory (2005, 2007, 2008), teaching for social justice as meeting the needs of individual students is based on considerations of individual students as independent of broader institutional structures. This also places more emphasis on the distribution of educational resources and opportunities rather than on the impacts of structural domination and oppression. By comparison, the three other conceptions of teaching for social justice identify individual students as affiliated with particular social and cultural groups. These three conceptions pay special attention to the dynamics of individual and group relations in particular situations, and thereby provide a basis for equalizing such power relations.

The findings of McDonald $(2005,2007,2008)$ indicate that both paradigms of justice, redistribution and recognition, are embedded in individuals' conceptions of teaching for social justice, but they are not always understood by individuals as co-fundamental. They also imply that many education policies and practices for promoting social justice may end up attending to one aspect of social justice at the expense of the other when there is no deliberate effort to integrate redistribution and recognition.

North's (2009a) Teaching for Social Justice: Voices from the Front Lines provides a vision for integrating redistribution and recognition in teaching and learning. What kind of learning experiences do children need to become knowledgeable, caring, and active citizens? What should students know and be able to do to become agents for social justice? In response to these questions, North (2009a) contended that educators should help all students develop multiple types of literacy to experience academic success in current school settings, as well as contribute to the betterment of society by working toward social justice. In her theory, literacy does not mean merely reading and writing skills, but includes abilities to fully engage in a school curriculum, as well as to contribute to building a better community and society. ${ }^{2}$ Sensoy and DiAngelo (2012) also viewed literacy as comprehensive in characterizing social justice illiteracy. They explained:

We think of these gaps of school-wide social justice illiteracy and argue that this illiteracy is not due to a lack of information alone. Rather, social injustice depends on this illiteracy; it is not benign or neutral but actively nurtured through many forces and serves specific interests. Social justice illiteracy prevents us from moving forward to create a more equitable society. (p. xvii)

North's (2009a) five types of literacy include functional, critical, relational, democratic, and visionary. In this article, her literacies are conceptualized as a fivefold framework of teaching for social justice in conjunction with scholarship borrowed from the field of multicultural education, particularly the work of Geneva 
Gay (2012a), to better explain the relationship between teaching for social justice and multicultural education.

In regards to teaching for social justice, educators often discover a tension between functional literacy and critical literacy. Functional literacy refers to the ability to live appropriately as an autonomous and informed citizen (Gutstein, 2006). Thus, educators who emphasize functional literacy have great interest in helping students develop the reading and writing abilities needed to function effectively in a democratic society, and in transmitting mainstream norms and values to all students (Ladson-Billings, 1995; Poole, Reynolds, \& Atkinson, 2011). Although the teaching of functional literacy is based on conservatism, in reality, it helps students from racially and ethnically marginalized groups gain access to and participate effectively in an open and free market of competitive society where these students are expected to "pull themselves up by their bootstraps" (Jenks, Lee, \& Kanpol, 2001, p.91). In the realm of multicultural education, various efforts on behalf of underrepresented students' academic success are advocated by equity-oriented pedagogy such as culturally responsive pedagogy (Gay, 2010; Ladson-Billings, 1995).

According to North (2009a), functional literacy also includes skills for higherorder thinking. Developing students' higher-order thinking is essential for promoting both redistribution and recognition because it cultivates academic skills that all students need to become competitive in capitalistic societies. It also equips them with intellectual abilities to analyze, synthesize, and evaluate knowledge and information that can be used as tools for their further investigation of injustices embedded in texts (Newmann, 1990).

By comparison, critical literacy refers to the ability to challenge existing paradigms of knowledge, question institutionalized power relations, and build strategies to act for equity and social justice (North, 2009a). It includes forms of critical consciousness such as analyzing texts by using strategies for uncovering underlying messages, raising questions about who benefits from particular knowledge claims, and critically identifying the political investments embedded in those claims. Furthermore, students with critical literacy are expected to take part in challenging knowledge claims (Freire, 1993; Wade, 2007).

Gay (2012a) advocated the teaching of critical literacy, contending that "education interventions that go beyond high academic performance, career readiness, and standardized test scores to deal effectively with these challenges" (p. 2) should be necessities rather than exceptionalities. She noted that, if students are to become informed and skilled social change agents, "they should understand the differential nature and complexities of societal, individual, and institutional reform" (p. 8). This compels educators to push students to move beyond functioning within the current system toward fighting against it.

Although functional literacy and critical literacy have different foci, they are not mutually exclusive, but are interactive in helping students to become agents for social justice. To achieve the goal of teaching for social justice, educators need to look at this reality more closely. Developing only functional literacy without 
critical literacy keeps social injustice unchallenged, while focusing too heavily on critical literacy without functional literacy might fail to empower students to take powerful legal, socioeconomic, and ethical positions that enable them to effectively advocate for social justice. North (2009a) also pointed out that it is critical literacy that helps students assess the existing states of unjust society, but it is functional literacy that helps them "take advantage" of the system so that they can more effectively challenge it (p.31).

Simply put, even though functional literacy is not directly related to challenging current structural injustices, it plays a significant role in getting students ready to better exercise critical literacy by supporting their success in a free market of competition in which the fittest survives (Jenks, Lee, \& Kanpol, 2001). Delpit (1995) identified the instrumental value of functional literacy as helping other people's children experience success in the existing system so that they can use it in challenging the system in strategic rather than subtractive ways. She explained:

They [teachers] can discuss openly the injustices of allowing certain people to succeed, based not upon merit but upon which family they were born into, upon which discourse they had access to as children.... Only after acknowledging the inequity of the system can the teachers' stance then be "Let me show you how to cheat!" And of course, to cheat is to learn the discourse which would otherwise be used to exclude them from participating in and transforming the mainstream. (p. 165)

Cho and DeCastro-Ambrosetti (2005) more explicitly identified functional and critical literacies as co-fundamental in promoting social justice. They suggested that effective educational programs should include social, economic, and political structures that affect students' lives along with identifying effective instructional strategies and methods that help them experience academic achievement. These two literacies, therefore, are regarded as complementary goals that should be simultaneously developed in an integrative way.

Relational literacy is the ability to understand mutual connections among humans; to consider others without bias and prejudice; and to care for each other within and beyond school walls (North, 2009a). Wade (2001) highlighted the significance of relational literacy by stating that "at the core of social justice lies both the belief in the equal worth of each person as well as the willingness to act from a place of both morality and care in upholding that belief" (p. 25). Although relational literacy should be nurtured alongside functional literacy, according to Gay (2012a), discontinuities between these two are still pervasive:

While the U.S. proclaims commitment to ethics of individuality, meritocracy, and democracy (as a style of living as well as government), it also recognizes the necessity of community, collaboration, and interdependence. Yet contradictions of these values abound in all levels of society. (p. 1)

Relational literacy also includes the principle of critical care, which refers to the breakdown of the traditional relationships between teachers and students in 
which the teacher acts like a banker who deposits knowledge and skills into the passive students (Freire, 1970). Critical care leads teachers to taking a co-learner role and developing reciprocal relationships with students centered on "mutual trust, respect, and responsibility" (North, 2009a, p. 107). Although North associated critical care with relational literacy, it also can be a part of critical literacy in that it encourages a transformative approach that redefines existing power relations (Cho, 2016).

North (2009a) argued that relational literacy cannot be taught and that students can understand it only when their teachers are treating them with respect. Gay (2012a), however, expressed a different view in that she believes students can learn specific skills needed to care for others, as they learn other skills. She explained that these skills must be taught intentionally by teachers who are competent in caring inside and outside of school walls. bell hooks (1994) also used the notion of engaged pedagogy, which demands joint teacher-students responsibility for learning, and emphasized that teachers should "transgress those boundaries that would resign each pupil to a rote, assembly-line approach to learning" (p. 3). Particularly, a deliberate intervention to help students learn critical care is pivotal because these learning experiences play a significant role in promoting social justice by preparing them to advocate for the rights and well-being of underrepresented people (Dolby, 2012; Goodman, 2000; Wade, 2000).

Democratic literacy refers to the ability to promote the common good and resolve various conflicts without resorting to physical force (North, 2007). Developing students' democratic literacy leads them to "participating in the same affairs of local, national, and global communities, as well as critical assessments and collective transformation of unjust social, political, and economic structures" (North, 2009a, p. 130). The classroom is an opportune space for democratic literacy learning in that students can practice making decisions across their differences and subsequently become politically enlightened and engaged citizens who are capable of transforming their communities and societies (Parker, 2006).

Though important, teaching democratic literacy can fall into a potential pitfall of failing to incorporate diverse cultural and ethnic communication styles: it implicitly favors consensus-oriented Western and middle-class codes of behavior in which dissent is regarded as unhealthy or unproductive, and minority opinions are thus ignored or disinvited (Pattillo, 2007; Stitzlein, 2014). Gay (2012a) highlights dissent as so fundamental to a strong democratic society that students should learn how to express these thoughts in the classroom ${ }^{3}$. She also argues that students need education that empowers them to resist conformity, and explains why it is especially important in the $21^{\text {st }}$ century:

[Many youth] don't even think to question unspoken motivation embedded in commercial and social advertising, or the various contenders for their allegiance. Consequently, they are very vulnerable to mind manipulation and the power of persuasions. It seems easier to just go with the flow, to use a popular expression, to do what everyone else is doing, and to find comfort, identity, and/or affiliation in the crowd. (Gay, 2012a, p. 5) 
Finally, visionary literacy encourages teachers and students to envision a future in which they play a key role in promoting justice, equity, and democracy. This literacy includes the individual and collective perseverance needed to maintain hope even in difficult situations (North, 2009a). The notion of visionary literacy coincides with that of grit, as Duckworth (2016) defined, that consistently motivates students to overcome unexpected obstacles and actualize their goals and dreams. It is necessary to develop visionary literacy, but an overemphasis on visionary literacy can lead to racist constructions: critics have argued that grit tends to attribute students' failure to individuals' dispositions rather than institutional and social structural inequality. Therefore, it has harmed underrepresented students by diffusing focus on academic, social, and financial support for these students (Blad, 2015; Kohn, 2016).

More recent scholarship in the field offers theoretical frameworks for social justice education. Picower (2012) suggested six elements of social justice curriculum design which help elementary teachers better implement key concepts of social justice education in their day-to-day classroom lessons. The six elements include (a) self-love and knowledge, (b) respect for others, (c) issues of social injustice, (d) social movement and social change, (e) awareness raising, and (f) social action. Her innovative framework rejects the sole emphasis on social activism by providing teachers with a new lens to understand social justice education, whereby developing students' cultural identity and sensitivity is requisite for students' comprehension of the devastating aspects of social injustice issues. Despite its wider scope, however, this framework does not directly address educational equity; hence, it fails to take a more integrative approach to social justice advocacy in a negotiation with the current education system. For example, the six elements rarely provide teachers with useful tools for helping students experience academic success while resisting curriculum standardization and the school accountability system. However, when the six elements are supported by North's (2009a) five literacies, especially the concept of functional and democratic literacies, they can provide teachers with a conceptual framework that helps them take more integrative and effectual approaches to social justice curriculum design.

More broadly, the five-fold framework of teaching for social justice (North, 2009a) supports both the redistribution and recognition models of justice. The five literacies are inseparable, but specific ones can more effectively serve specific paradigms of social justice. For example, a strong inclination toward teaching functional literacy advocates the redistribution view of justice in that it concerns the equitable distribution of education opportunities and resources; critical literacy advocates the recognition view of justice in that it concerns institutional injustices that create unequal distributions; and relational literacy supports the recognition view of justice in that it concerns individuals' interactions based on mutual respect and humanitarian approaches built upon the imperatives of interdependencies. Furthermore, teaching the five types of literacies includes a variety of goals, from conservative to more critical, discussed in the domain of multicultural education. The substantive relationship between teaching for social justice and multicultural education is discussed in more detail in the remainder of this article. 


\section{Negotiating Two Discourses: Teaching for Social Justice and Multicultural Education}

Teaching for social justice and multicultural education discourses are generally regarded as compatible with one another, but the relationships between the two have often been interpreted differently in existing scholarship in the field. In Sleeter's and Grant's (1999) Making Choices for Multicultural Education: Five Approaches to Race, Class, and Gender, social justice education, which they initially labeled as multicultural education that is social reconstructionist, was considered one of five approaches to multicultural education. It was emphasized as an ultimate goal of multicultural education in a later edition. In a similar vein, Sensoy and DiAngelo (2012) recognized social justice education as a more transformative approach to multicultural education and defined it as education to develop students' abilities to "recognize inequality deeply embedded in the current structure of society" (p. xviii).

Teaching for social justice is often regarded as a re-invigorated version of multicultural teacher education, which reflects the 1960s civil rights movement (Dolby, 2012). Another relationship identified by many educators in the field of teacher education is that teaching for social justice advocates a more integrated approach for promoting social justice and equity than earlier multicultural teacher education (Baldwin, Buchanan, \& Rudisill, 2007; Cochran-Smith, 2009; Kapustka, Howell, Clayton, \& Thomas, 2009; McDonald, 2007; McDonald \& Zeichner, 2009). More recent scholarship such as Dover $(2009 ; 2015)$ and Dover, Henning, and Agarwal (2016) contends that existing accounts of teaching for social justice draw from a wide range of equity-oriented theoretical frameworks, including ethnic studies, critical pedagogy, culturally responsive education, social justice education, and multicultural education. The overlap between teaching for social justice and multicultural teacher education is inevitable because a theory of teaching for social justice has been developed deductively rather than inductively, from diverse settings, with diverse aims, and within diverse disciplines, including multicultural education.

Despite some efforts to make a conceptual distinction between teaching for social justice and multicultural education or to designate multicultural education as one of the foundational frameworks for teaching social justice, these two are compatible with one another, at least in the context of teaching and learning: both aim to challenge injustices and inequalities in all forms (redistribution and recognition) and empower students to become agents to make the world better (Martin \& Van Gunten, 2002).

This claim becomes more apparent by comparing North's (2009a) five social justice literacies with Gay's (2012b) four purposes of multicultural education. Gay (2012b) organized various goals of multicultural education, provided by Christine Bennett, Christine Sleeter, Carl Grant, and James Banks, who are among the U.S.-originated leaders in the multicultural education field, into four related categories: academic, social, political, and cultural. Academic goals use the cultural heritages and experiences of underrepresented students to improve their 
ethnic pride and cultural competence along with academic performance and create a community-based curriculum as an alternative to a standardized curriculum. These claims are supported by well-known scholarship in the field, such as culturally responsive pedagogy (Gay, 2010; Ladson-Billings, 1995), funds of knowledge (Gonzalez et al., 1995), and content integration (Banks, 1994). Social and political goals include critically investigating mainstream knowledge claims; becoming aware of discriminatory practices; and combating and correcting inequalities, oppression, and exploitation in all forms. Cultural goals include developing cultural identity, teaching empathy, reducing prejudice, and developing intercultural competence by deliberative interventions.

Empowering students with social justice literacies (North, 2009a) can be a powerful means for realizing the various goals of multicultural education. Although the social justice literacies and multicultural education goals are related, particular literacies more effectively serve the specific goals of multicultural education. For example, empowering students with functional literacy, relational literacy, and critical literacy can help them achieve the academic, cultural, and social/political goals of multicultural education, respectively. A deliberate integration of social justice literacies, therefore, contributes to meeting the comprehensive goals of multicultural education and to promoting social justice in which both redistribution and recognition are considered co-fundamental.

In a similar vein, Sleeter's (2015) four dimensions of social justice teaching are compatible with the goals of multicultural education. These four dimensions are:

1. To situate families and communities within an analysis of structural inequalities;

2. To develop relationships of reciprocity with students, families, and communities;

3. To teach to high academic expectations by building upon students' cultures, languages, experiences, and identities;

4. To create and teach an inclusive curriculum that integrates marginalized perspectives and explicitly addresses issues of inequity and power.

The first dimension rejects Harrington's (1997) often quoted phase, the culture of poverty, and supports the concept of funds of knowledge (Gonzalez et al.,1995). The second dimension highlights reciprocal relationship among school community members, and the third dimension advocates culturally responsive teaching (Gay, 2010; Ladson-Billings, 1995) in conjunction with grassroots curriculum development resisting the current system of curriculum standardization. The fourth dimension presents the ideas of democratic activism and grassroots curriculum development. It is noteworthy that the four dimensions of social justice teaching mirror the academic, cultural, social, and political goals of multicultural education.

Teaching for social justice and multicultural education overlap in more areas than the structural level of justice and social activism and share a high degree of affinity. Dover's (2009) three-fold framework for teaching for social justice, having 
been built upon Cochran-Smith's (2004) six principles of teaching for social justice, is also a good example. The framework is composed of (a) teachers' expectations and classroom pedagogies; (b) family engagement, constructivism, and cultural responsiveness; and (c) explicit instruction about oppression, equity, and activism. Along with Dover's framework, existing theoretical frameworks for teaching for social justice (e.g., Agarwal-Rangnath, 2013; Mills \& Ballantyne, 2010) parallel the goals of multicultural education.

The intersection of the theory of teaching for social justice and the goals of multicultural education also implies that two paradigms of social justice can be mutually supported by one another in the practice of education. The meanings of five social justice literacies are inseparable, as are those of four purposes of multicultural education and those of social justice. However, some social justice literacies and multicultural education purposes can better serve specific aspects of social justice. For instance, the redistribution model of justice can be better supported by developing students' functional literacy and realizing the academic goal of multicultural education while the recognition model of justice can be more effectively promoted by developing students' relational literacy and critical literacy and realizing the cultural, social, and political goals of multicultural education. It implies that the two discourses would need to make collective efforts to promote redistribution and recognition (i.e., attending to the academic, social, political, and cultural goals of multicultural education by designing K-12 curriculum or teacher education programs into which the five social justice literacies are integrated).

In sum, redistribution and recognition would not be interwoven throughout the practice of promoting social justice if teaching for social justice and multicultural education defined their shared territories as only social structures and social activism. In order for education policies and practices to contribute to a mutual development of redistribution and recognition, scholars need to link the discourses of teaching for social justice and multicultural education more closely, rather than merely assuming that the two discourses intersect only in the areas of societal structures and social activism.

\section{Social Justice for Flourishing Lives: Personal Literacy}

Existing scholarship in the fields of multicultural education and teaching for social justice, including the works of North (2009a) and Gay (2012b), provides useful tools for advocating both redistribution and recognition models of social justice. However, there is little discussion about cultivating individual students' talents and interests and achieving diverse potentials. Although attending to individual students' academic needs is one of the top priorities in teaching for social justice, education should go further than that. As Bennett (2001) argues, education also needs to attend to individual students' rights to flourish in their lives to their fullest potential. In every classroom, all students need to be provided with rich and frequent opportunities to discover their special talents and interests and to develop them throughout the school years. I term personal literacy as the ability to 
understand and realize one's special talents and interests, which cannot be replaced with those of others.

By developing personal literacy, students can also become "a friend of their minds" (Morrison, 1987, p.25): understanding what they are good at, what they want to do, who they are, and who they want to become. A deliberate and systematic intervention to develop students' personal literacy avoids cultural essentialism, the potential pitfall of multicultural education (Gay, 2010). This literacy also helps students connect social justice literacies to their lives in more meaningful ways by providing a pathway to a better understanding of what it means to develop social justice literacies in their lives. When students develop personal literacy along with the other five literacies, they can also contribute to the broader community and society by responding to the question, "How can I use these literacies to develop my mind, enrich my life, and advocate for others?" with an enhanced blend of confidence, commitment, and competence.

\section{Concluding Remarks}

This article explained the relationships among the concepts of social justice, teaching for social justice, and multicultural education, and discussed how the substantive meanings of social justice-including redistribution and recognitioncan be better served by the integration of teaching for social justice and multicultural education. I also suggested a new social justice literacy-personal literacy - as a means to promote social justice in conjunction with other social justice literacies. Such an integrated framework outlined in this article is a viable tool for evaluating current practices aimed at promoting social justice. As reflected in the possible conflicts between redistribution and recognition, teachers and educators often face tensions among social justice literacies and among the goals of multicultural education. This theoretical review provided theorists, researchers, scholars, and practitioners with an explanation of the root of these conflicts and an argument for the deliberate integration of six different fundamental literacies in actualizing social justice.

\section{Notes}

1. Even though the term teaching for social justice is often used exclusively in the context of teacher education, North's (2009a) five-fold framework of teaching for social justice mainly discusses students' knowledge and skills needed to promote social justice and equity rather than those of in-service/preservice teachers. In this article, teaching for social justice is not necessarily equated with social justice teacher education but considered as a concept that permeates the contexts of teacher education and K-12 education. The flexible use of this term is based on the premise that what students should know and 
be able to do is mutually associated with what teachers should know and be able to do.

2. In order to distinguish North's (2009a) definition of literacy from the traditional notion of literacy (i.e., reading and writing), I deliberately used the term "social justice literacies" (Poole, Reynolds, \& Atkinson, 2011, p. 1), in which functional, relational, critical, democratic, and visionary literacies are conceptually included.

3. Due to its idea of challenging mainstream norms, the ability to dissent can also be seen as a part of critical literacy.

\section{Acknowledgment}

I would like to thank the editors and anonymous reviewers for their constructive feedback. I would like to give special thanks to Dr. Geneva Gay for her intellectual engagement and endless encouragement. In addition, I am grateful to Dr. Walter Parker, Dr. Kenneth Zeichner, and Dr. Yong-Chool Ha for their thoughtful comments on earlier drafts of this paper.

\section{References}

Agarwal-Rangnath, R. (2013). Social studies, literacy, and social justice in the Common Core classroom: A guide for teachers. New York, NY: Teachers College Press.

Baldwin, S. C., Buchanan, A. M., \& Rudisill, M. F. (2007). What teacher candidates learned about diversity, social justice, and themselves from service-learning experience. Journal of Teacher Education, 58(4), 315-327.

Banks, J. A. (1994). An introduction to multicultural education. Needham Heights, MA: Allyn and Bacon.

Bennett, C. (2001). Genres of research in multicultural education. Review of Educational Research, 71(2), 171-217.

Blad, E. (2015, January 26). Emphasis on 'grit' is unfair to some students, critics say. Education Week, Retrieved from http://blogs.edweek.org/edweek/ rulesforengagement/2015/01/emphasis_on_grit_is_unfair_to_some_stude nts_critics_say.html

Cho, G., \& DeCastro-Ambrosetti, D. (2005). Is ignorance bliss? Pre-service teachers' attitudes toward multicultural education. The High School Journal, 89(2), 24-28. 
Cho, H. (2016). Creating a third space: Teacher beliefs and practices in curriculum reform for multicultural education (Doctoral dissertation). Seattle, WA: University of Washington.

Cochran-Smith, M. (2004). Walking the road: Race, diversity, and social justice in teacher education. New York, NY: Teachers College Press.

Cochran-Smith, M. (2009). Toward a theory of teacher education for social justice. In A. Hargreaves, A. Lieberman, M. Fullan, \& D, Hopkins (Eds.), Second international handbook of educational change (pp. 445-467). Rotterdam, Netherlands: Springer.

Delpit, L. (1995). Other people's children: Cultural conflict in the classroom. New York, NY: New Press.

Dolby, N. (2012). Rethinking multicultural education for the next generation: The new empathy and social justice. New York, NY: Routledge.

Dover, A. (2009). Teaching for social justice and K-12 student outcomes: A conceptual framework and research review. Equity and Excellence in Education, 42(4), 506-524.

Dover, A. (2015). Teaching for social justice and the Common Core: Justiceoriented curriculum for language arts and literacy. Journal of Adolescent \& Adult Literacy, 59(5), 517-527.

Dover, A. G., Henning, N., \& Agarwal-Rangnath, R. (2016). Reclaiming agency: Justice-oriented social studies teachers respond to changing curricular standards. Teaching and Teacher Education, 59, 457-467.

Duckworth, A. (2016). Grit: The power of passion and perseverance. New York, NY: Simon and Schuster.

Fraser, N. (1995). Recognition or redistribution? A critical reading of Iris Young's Justice and the Politics of Difference. Journal of Political Philosophy, 3(2), 166-180.

Fraser, N. (1997a). A rejoinder to Iris Young. New Left Review, 223, 126-129.

Fraser, N. (1997b). Justice interruptus: Critical reflections on the 'post-socialist' condition, New York, NY: Routledge.

Fraser, N., \& Honneth, A. (2003). Redistribution or recognition?: A politicalphilosophical exchange. New York, NY: Verso.

Freire, P. (1970). Pedagogy of the oppressed. New York, NY: Seabury Press.

Freire, P. (1993). Pedagogy of the city. New York, NY: Continuum.

Gay, G. (2010). Culturally responsive teaching: Theory, research, and practice. New York, NY: Teachers College Press.

Gay, G. (2012a). Our children need..."Education for resistance". Journal of Educational Controversy, 6(1), 1-12. 
Gay, G. (2012b). Multicultural education, purposes, and goals. In J. A. Banks (Ed.), Encyclopedia of diversity in education (pp. 1548-1553). Thousand Oaks, CA: Sage.

Gewirtz, S. (1998). Conceptualizing social justice in education: Mapping the territory. Journal of Education Policy, 13(4), 469-484.

Gewirtz, S. (2006). Towards a contextualized analysis of social justice in education. Educational Philosophy and Theory, 38(1), 69-81.

Giroux, H. A. (1992). Border crossings: Cultural workers and the politics of education. London, United Kingdom: Routledge.

Gonzalez, N., Moll, L. C., Tenery, M. F., Rivera, A., Rendon, P., Gonzales, R., \& Amanti, C. (1995). Funds of knowledge for teaching in Latino households. Urban Education, 29(4), 443-470.

Goodman, D. (2000). Motivating people from privileged groups to support social justice. Teachers College Record, 102(6), 1061-1085.

Grant, C. A., \& Agosto, V. (2008). Teacher capacity and social justice in teacher education. In M. Cochran-Smith, S. Feiman-Nemeser, D. J. McLntyre, \& K.E. Demers (Eds.), Handbook of research on teacher education: Enduring questions in changing contexts (pp. 175-200). New York, NY: Routledge.

Gutstein, E. (2006). Reading and writing the world with mathematics: Toward a pedagogy for social justice. New York, NY: Taylor \& Francis.

Harrington, M. (1997). The other America. New York, NY: Scribner.

hooks, b. (1994). Teaching to transgress: Education as the practice of freedom. New York, NY: Routledge.

Hytten, K. (2006). Education for social justice: Provocations and challenge. Educational Theory, 56(2), 221-236.

Jenks, C., Lee, J. O., \& Kanpol, B. (2001). Approaches to multicultural education in preservice teacher education: Philosophical frameworks and models for teaching. The Urban Review, 33(2), 87-105.

Kapustka, K. M., Howell, P., Clayton, C. D., \& Thomas, S. (2009). Social justice in teacher education: A qualitative content analysis of NCATE conceptual frameworks. Equity \& Excellence in Education, 42(4), 489-505.

Kohn, A. (2016). The myth of the spoiled child: Coddled kids, helicopter parents, and other phony crises. Boston, MA: Beacon Press.

Kumashiro, K. K. (2002). Troubling education: Queer activism and anti-oppressive pedagogy. New York, NY: Routledge Flamer.

Ladson-Billings, G. (1995). But that's just good teaching! The case for culturally relevant pedagogy. Theory Into Practice, 34(3), 159-165.

Mapel, D. (1989). Social justice reconsidered. Urbana, IL: University of Illinois Press. 
Martin, R. J., \& Van Gunten, D. M. (2002). Reflected identities: Applying positionality and multicultural social reconstructionism in teacher education. Journal of Teacher Education, 53(1), 44-54.

McDonald, M. (2005). The Integration of social justice in teacher education: Dimensions of prospective teachers' opportunities to learn. Journal of Teacher Education, 56(5), 418-435.

McDonald, M. (2007). The joint enterprise of social justice teacher education. Teachers College Record, 109(8), 2047-2081.

McDonald, M. (2008). The pedagogy of assignments in social justice teacher education. Equity \& Excellence in Education, 41(2), 151-167.

McDonald, M., \& Zeichner, K. (2009). Social justice teacher education. In W. Ayers, T. Quinn, \& D. Stovall (Eds.), Handbook of social justice in education. New York, NY: Routledge.

Mills, C., \& Ballantyne, J. (2010). Pre-service teachers' dispositions towards diversity: Arguing for a developmental hierarchy of change. Teaching and Teacher Education, 26(3), 447-454.

Morrison, T. (1987). Beloved. New York, NY: Plume Contemporary Fiction.

Newmann, F. M. (1990). Higher order thinking in teaching social studies: A rationale for the assessment of classroom thoughtfulness. Journal of Curriculum Studies, 22(1), 41-56.

North, C. E. (2006). More than words? Delving into the substantive meaning(s) of "social justice" in education. Review of Educational Research, 76(4), 507535.

North, C. E. (2007). Teaching for "social justice"?: Exploring the meanings, implications, and promise of education's latest catchphrase (Doctoral dissertation). Madison, WI: University of Wisconsin-Madison.

North, C. E. (2009a). Teaching for social justice?: Voices from the front lines. Boulder, CO: Paradigm Publishers.

North, C. E. (2009b). The promise and perils of developing democratic literacy for social justice. Curriculum Inquiry, 39(4), 555-579.

Parker, W. C. (2006). Talk isn't cheap: Practicing deliberation in school. Social Studies and the Young Learner, 19(1), 12-15.

Pattillo, M. (2007). Black on the block: The politics of race and class in the city. Chicago, IL: University of Chicago Press.

Picower, B. (2012). Using their words: Six elements of social justice curriculum design for the elementary classroom. International Journal of Multicultural Education, 14(1), 1-17.

Poole, J., Reynolds, K., \& Atkinson, M. (2011). Professional book review [Review of the book Teaching for social justice?: Voices from the front lines, by $\mathrm{C}$. North]. International Journal of Multicultural Education, 13(1), 1-3.

Rawls, S. J. (1972). A theory of justice. Oxford, United Kingdom: Clarendon Press. 
Sensoy, Ö., \& DiAngelo, R. (2012). Is everyone really equal?: An introduction to key concepts in social justice education. New York, NY: Teachers College Press.

Sleeter, C. E. (2015, February). Deepening social justice teaching. Journal of Language \& Literacy Education. Retrieved from http://jolle.coe.uga.edu/wpcontent/uploads/2014/01/SSO_Feb2015_Template.pdf

Sleeter, C. E., \& Grant, C. A. (1999). Making choices for multicultural education: Five approaches to race, class, and gender. New York, NY: Wiley.

Stitzlein, M. (2014). Teaching for dissent. Boulder, CO: Paradigm Publishers.

Vincent, C. (2003). Social justice, education and identity, London, United Kingdom: Routledge/Falmer.

Wade, R. C. (2000). Service-learning for multicultural teaching competency: Insights from the literate for teacher educators. Equity \& Excellence in Education, 33(3), 21-30.

Wade, R. C. (2001). Social action in the social studies: From the ideal to the real. Theory into Practice, 40(1), 23-28.

Wade, R. C. (2007). Social studies for social justice: Teaching strategies for the elementary classroom. New York. NY: Teachers College Press.

Young, I. M. (1990). Justice and the politics of difference. Princeton, NJ: Princeton University Press.

Young, I. M. (1997). Unruly categories: A critique of Nancy Fraser's dual systems theory. New Left Review, 222, 147-160.

Young, I. M. (2011). Responsibility for justice. London, United Kingdom: Oxford University Press.

Zeichner, K. (2011). Teacher education for social justice. In M. R. Hawkins (Ed.), Social justice language teacher education (pp. 7-22). Bristol, United Kingdom: Multilingual Matters.

\section{Author Contact}

Hyunhee Cho: hyunhc@uw.edu

Education, 52, Ewha Women's University, Ewhayeodae-gil, Seodaemun-gu, Seoul 03760, Republic of Korea 